\title{
Pastoralist Resource Use and Access in Somalia: A Changing Context of Development, Environmental Stress, and Conflict
}

\author{
Jon D. Unruh
}

Unruh JD (1995) Pastoralist resource use and access in Somalia: a changing context of development, environmental stress, and conflict. In: Sorenson J (ed.) Disaster and Development on the Horn of Africa. Macmillan, London

\section{Introduction}

The turmoil in Somalia in the early 1990s has had a debilitating impact on pastoralists and livestock herding activities. Over half of the estimated 8.4 million somalis are nomadic or semi-nomadic herders subject to the vagaries of an arid climate. Pastoralism is the most important agricultural enterprise in the country and will continue to be the basis for food production for future populations (Conze and Labahn 1986:15; Handulle and Gay 1987:36; Markakis 1993:9; Unruh 1993a:308; Lewis 1975:1). The decimation of herds and the impoverishment of nomads beyond the capacity of indigenous recovery mechanisms will compromise food production in the country for some time, while creating very large refugee populations.

Somalia possesses the greatest proportion of pastoralists in Africa. Prior to the war and famine of the early 1990s, approximately 65 percent of the national population participated in nomadic pastoralism, while 80 percent of the population engaged in livestock raising of some kind (Samatar 1989a:41; Handulle and Gay 1987:36). In the 1980s livestock production accounted for 80\% to 90\% of export earnings (Laitin 1993:136; Handulle and Gay 1987:36; Bennet et al 1986:10). The importance of pastoralism is to a large degree due to the biophysical setting, 1 which contains very large areas of arid and semi-arid rangeland and comparatively limited areas suitable for intensive agriculture (Laitin and Samatar 1987:22). The focus of nomadic material life and the mainstay of somali pastoralism is the camel, which in the past served as the principal medium of exchange in many parts of the interior (Laitin and Samatar 1987:24). In times of famine camels have outlived less hardy livestock, providing the needed milk, meat and transport that stand between the nomad and starvation (Laitin and Samatar 1987:24).

In recent decades, however, changes in access to dry season and drought grazing and watering locations (the most valuable asset for pastoralists) resulted in overgrazing and land degradation, and created conditions of ecological stress in many rangeland areas, and considerably reduced options for transhumant herders (Laitin and Samatar 1987:127; Krokfors 1984:306; Markakis 1993:7; Hurni 1993:20). Land degradation in turn was perceived to be a serious obstacle to pastoral sector development (Krokfors 1984:306). A deteriorating and shrinking resource base increased discord over access to adequate land and water resources needed to maintain herds (Markakis 1993:13). Ephemeral coalitions between lineages and their constituent units (a common feature in pastoral societies) were created and abandoned in a continuing attempt to facilitate access to dwindling resources (Samatar 1993:73). This meant increased vulnerability for pastoralists and the range resources they occupied, as the country experienced war and famine in the late $1980 \mathrm{~s}$ and early 1990s.

As Somalia emerges from these conditions, rangeland livestock production will be essential to feed a growing population off a land resource where pastoralism may not only be the only sustainable use, but may be one of the few assets possessed and easily exploited by a largely agrarian economy. This chapter examines somali pastoralist resource use in the context of changing resource access rights. The 
configuration of these rights are influenced by, and in turn affect development activities, ecological stress, and conflict. Following a brief description of the pastoral systems, along with some important pastoralist-related development efforts prior to the collapse of the somali state, the chapter focuses on the interplay between development, the Somali segmentary social order, and conditions of environmental stress and conflict. This interplay produced the circumstances within which most, if not all pastoralists found themselves in the late 1980s; to be replaced by widespread insecurity as the dominant context within which pastoralists pursued resource use options in the early 1990s.

\section{Pastoral Systems}

Most nomads keep a mix of livestock species 2 to maximize benefits and minimize risks. This takes advantage of variations among species with respect to drought tolerance and the utilization of different types of vegetation, and supplies nomads with milk, meat, transport, investment, and income (Samatar 1989a:6). Camels comprise approximately half of the biomass of most transhumant herds for all regions. The other half varies from north to south, mainly sheep and goats in the north and center, and cattle in the south. The proportion of drought resistant stock (camels and goats) traditionally increased in response to drier climatic conditions (Samatar 1989a:28).

Mobility and flexibility are required to make good use of meager range resources, thus units of production are small and widely dispersed (Samatar 1989b:28). The logic of the pastoral economy is to minimize risk in order to secure preservation of the family (Samatar 1989a:6; Samatar 1989b:28). As an adaptation to ecosystems in which forage and water are critical parameters, transhumant herding largely depends on dry season forage within reach of dry season watering points (Scudder 1989:6; Johnson 1969:5; Breman et al 1979:227). When forage is depleted or access to it and adjoining water supplies are interrupted, the result can be land degradation, livestock die-offs, conflict, and rapid sales as pastoralists seek to realign resource access arrangements, utilize already marginal land, and cope with reductions in herd viability. Nomadic cooperation, bound by lineage and alliance, traditionally related primarily to confrontation and hostility under ecological conditions in the acute competition for scarce resources (Lewis 1961:240). Dependence by several lineage-segments on common pasture and water creates tension, especially in the dry season, when pressure on land resources is greater and disputes increase (Lewis 1961:243). The lineage system and personal relationships between pastoralists facilitates a degree of insurance against stock loss by the possibility of borrowing animals from fellow stock-owners with a shared lineage or with whom exchange relationships exist. This occurs through the exercise of rights and obligations involved in such relationships, and carries with it an assurance of reciprocity (Poulsen 1990:146; Samatar 1989a:40; Ornas 1990:119). Membership in such groups, especially lineage groups, implies obligation to assist and be assisted in times of crisis (Ornas 1990:119).

In Somalia six major clan-families and their sub-groups (clans) retain access to most land (Figure 1) (Samatar 1993:72; Cassanelli 1982:16). Clan territories are not distinct. Instead they constitute general areas and home wells associated with particular groups (Gunn 1990:114). Land traditionally is not alienated from the clan. If a pastoralist from a neighboring clan is allowed to use grazing resources, the person becomes allied with the clan, rather than land being removed from the clan's territory (Gunn 1990:114).

There exists a dynamic overlap in the territorial orbit of different clans. This overlap increases in times of drought as members of one clan may intrude into another clan's territory when its own grazing and watering resources become scarce, provoking mutual hostilities, which in some cases have resulted in clan wars 
(Bennett 1991:31). While such a cycle of resource scarcity and territorial intrusion and confrontation among clans and segments thereof have always been a part of Somali pastoralism, such conflicts and wars have increased in recent decades due to declining ecological conditions (Bennett 1993:65) and increased in-access to traditional resources.

\section{Subsaharan Africa}

\section{The Development Context}

With few exceptions, livestock development attempts in subsaharan Africa have had two general objectives: increasing animal output for market, and rangeland conservation (Bennett 1986:146). Changes in land tenure are usually considered instrumental, with communal tenure singled out as a leading constraint. Many programs involved tenure reforms to reduce multiple resource use and access claims to specific grazing areas (Bennett 1986:146). Such a disposition toward individualization--especially notable in range conservation projects--operates with the rationale that only under individual tenure will herders use self-restraint in balancing herd size with carrying capacity, and abandon the notion that pastures exist elsewhere when depleted locally (Bennett 1986:146). However tenure reform often has not been effective in either growth of marketable livestock products, or conservation (Bennett 1986:149). One of the more important reasons for this is the need for transience in resource use given the high degree of spatial variability in rainfall patterns, and the quick response needed to take advantage of such a variable environmental base. Thus geographically prescribed land resources normally only have use value for a limited time in any season (Bennett 1986:149). Cyclic transhumant movements between seasonally available water and grazing resources are difficult to connect to individual tenure, which in most cases requires a technical infrastructure (Bennett 1986:150). Figure 1 illustrates the major patterns of Somali transhumance.

\section{Somalia}

\section{Rangeland conservation efforts}

From 1960 until the 1980s Somalia was one of the most aided countries in the world (Berg 1982:1). Range management was initially pursued as a conservation rather than a development issue. This favored range resources but not pastoralists, whose transhumant resource use strategies can be misunderstood by conservation science (Bennett 1986:12). The objective was to stabilize and improve range resources to increase quality livestock production and income for pastoralists (Bennett 1986:11, USAID 1979:3). Range resource control and improvement was seen as a bureaucratic activity requiring government intervention (Bennett 1986:11). Prior to the Barre administration there were no attempts to introduce range management schemes or improved breeding methods (with the exception of a few experimental stations) (Samatar 1989a:41).

There were few attempts to produce forage for livestock (Massey 1989:162). Pastoralists could usually obtain freely what crop residue was available in the dry season. If subsistence farmers were to grow fodder crops in a good rainfall year, when plenty of free crop residue was available and fewer transhumant livestock arrive in cropped areas to spend the dry season, the farmer would receive little or no money for a forage crop. This is a risk that subsistence farmers were unwilling to take. Large farms and plantations did not produce fodder crops for the same reasons. Government subsidy would have entailed construction and maintenance of storage facilities, and a long term commitment for purchase and transport of fodder. This arrangement would have aided both farmers and pastoralists, but the government pursued other priorities (Unruh 1991:97). 


\section{Cooperatives}

Under Barre creation of cooperatives was part of the effort to construct a socialist economy. The 1974 Law on Cooperative Development originally aimed to teach nomadic groups to share scarce range resources peacefully and efficiently, and to allow scientific management of the rangeland (Laitin and Samatar 1987:111). Generally the idea was to promote the regeneration of grazing lands and the creation of new watering holes. Fourteen cooperatives were created, with each participant family being allocated an exclusive 500-750 acre grazing area, and common lands available in times of drought. When these cooperatives were fully in place the government was to provide health and educational services and a marketing outlet for stock (Laitin and Samatar 1987:111).

In the late 1970 s more ambitious range cooperatives were attempted. With funding from the Food and Agriculture Organization, the UN Development Program, the Kuwait Arab Fund, and the US Agency for International Development, the Northern Rangelands Development Project got underway in 1977, with the Central Rangelands Development project following in 1979 (Laitin and Samatar 1987:111; Bennett 1986:10). Both projects encouraged nomads to create associations to discuss rotation of pasture lands, use of grazing reserves, and building of watering points (boreholes), as well as to work with technical personnel for rangeland management. In reality these associations accomplished little, and there has been little investigation of changes in the pastoral sector by the cooperative reforms (Laitin and Samatar 1987:111). Problems included a mismatch between grazing areas assigned to cooperatives and the needs of herds during drought when mobility was necessary; also contraction and expansion of herds with respect to drought cycles were not modified toward stable, intensified production, even though the rangelands initiatives were designed for this (Bennett 1986:13).

By 1979 the cooperative system was beginning to crowd smaller herd owners not members of a cooperative out of certain areas, as grazing lands were increasingly enclosed--even though one objective of the cooperatives was to ensure that nonmembers had access to pasture (Bennett 1986:13). Apart from the cooperative associations, were the longstanding grazing associations with indigenous roots in Somali social and political structures (Bennett 1986:13). These associations fit into the system of village and local government, and by 1979 there were 34 associations. Before assistance of any kind was directed to these groups however, they had to conform to the Rangeland Projects' determination of what was beneficial for livestock production, including grazing restrictions and water development (USAID 1979:3; Bennett 1986:14). Different operational rules for grazing cooperatives and grazing associations put these institutions in competition (Bennett $1986: 14)$.

\section{Livestock trade, resource access, and environmental stress}

A shrinking resource base for extensive livestock production together with drought affects terms of trade for pastoralists (Hutchison 1991:131). As land is degraded and inaccess to land and water cause these resources to become scarce and products decline, values for these can rise (Hutchison 1991:131). However with persistent drought livestock quickly depreciate in value at local markets as herders sell stock enfeebled by the degraded range, in order to purchase basic essentials (Hutchison 1991:131). Such deteriorating terms of trade for pastoralists are now well known indicators of approaching famine used in early warning systems (Hutchison 1991:131; Hutchinson 1991:27). On a larger scale, national and global market forces created a decline in the value of livestock products relative to what can be purchased by pastoralists (Hutchison 1991:132). During the twentieth century, the value of livestock products have been reduced to between half and one-tenth of their relative values in the middle of the previous century; with the periods of greatest 
change occurring during the 1950s and early 1970s. This decrease in value has led to very large increases in herd sizes, while impoverishing many smaller herd owners (Hutchison 1991:132).

The boom in livestock trade to the Middle East in the 1970s helped to raise relative values of livestock products, but Somalia's loss of Saudi Arabia as the principal livestock market in the early $1980 \mathrm{~s}$ led to a 66 percent decline in livestock exports (Hutchison 1991:84). The livestock trade with Saudi Arabia was heavily dependent on the yearly hadji market. Since the date of the hadji moves with respect to the Gregorian calendar, Somalia's ability to supply livestock was influenced by the seasonal availability of good pastures during the fattening period prior to shipment. Thus when the Somali dry season, the Jilaal, coincided with the months prior to the hadji, livestock exports were at risk (Hutchison 1991:84). The Saudi ban on Somali livestock was based on suspected rinderpest infection. While subsequently disproved, the ban on cattle remained while the restriction on sheep and goats was eventually lifted (Hutchison 1991:84).

In the livestock export sector a system known as franco valuta enabled northern livestock traders to accumulate significant foreign exchange. In the 1970s northern trading families used their profits to purchase real estate primarily in Mogadishu. In the 1980s they played a role in subsidizing the rebels fighting the government (Laitin 1993:142).

Regulation of market operations in an attempt to control resources in Somalia worsened terms of trade for many pastoralists, handicapping development efforts (Hutchison 1991:123). The government sought control by establishing the Hides and Skins Association, closing small ports on the Gulf of Aden and the Indian Ocean, and restricting local and international livestock trade. The government argued that private livestock traders were incapable of providing adequate marketing structures (Hutchison 1991:134). Trading networks were disrupted and livestock producers and traders were alienated from national efforts to market through the official association. While the economy stagnated a parallel market operated via an external network of Somali traders in East Africa and the Middle East (Hutchison 1991:134).

In many cases pastoralist self-sufficiency in Somalia was eroded by modern market mechanisms which transferred the responsibility for food security to systems under control of the state or international agencies. Such a dependence can have dramatic effects when these mechanisms are disrupted by famine and conflict (Hutchison 1991:124). This also raises the stakes connected with using food as a weapon (Hutchison 1991:125).

Increased market benefits associated with cattle production affected livestock production (RMR 1984:36; Gunn 1990:112-117). The proportion of cattle in the national livestock population increased while the proportion of goats decreased during 1952 - 1984 (RMR 1984:36). As well increased rainfed cropping and changes in vegetation caused by cutting, grazing, browsing and burning enhanced production of grasses and other herbaceous vegetation and decreased the abundance of bush and trees (RMR 1984:36). While this can be beneficial to cattle production in good years due to the increase in herbaceous biomass and a reduction in tsetse habitat (trees and bushes); in times of drought and famine the costs can be high for pastoralists. Browsers in somalia (camels and goats) are hardier than grazers (cattle and sheep), have wider forage preferences, and can be watered less. The protein provided by forage tree and bush species allow greater utilization of protein deficient grasses and crop residues, which otherwise would be consumed less and with less benefit to livestock (Unruh 1993c:32 and the references cited therein). A decrease in browsers and the vegetation to sustain them can make a pastoral livelihood based on extensive livestock production more vulnerable to drought. With prolonged drought, nomads progressively reduce their herds, with cattle being among the first species to go and camels the last. If there does not 
exist a herd of hardy animals able to support the household, an otherwise minor drought can have a heightened impact on a household that invested heavily in cattle. Thus a decrease in browse vegetative species and browsers would increase the vulnerability to periodic drought, positioning pastoralists in a worse situation with the onset of famine and conflict when access to optimal grazing lands is disrupted.

As well, post drought restocking efforts important in herd reconstitution begin best with small stock (goats and sheep), most notably goats due to their wide forage preferences and short gestation periods compared to cattle, and low purchase cost, greater survival capacity, and drought resistance (McCabe 1990a:151; Unruh 1993a and the references cited therein).

Improved veterinary services and development of a large number of watering sites in areas not previously used during the dry season due to lack of water improved livestock survivability, and led to large increases in herd size of about 3 percent per year (Al-Najim and Briggs 1992:358). While the percentage of pastoralists in the total population has remained constant since the turn of the century, the livestock population has doubled and perhaps tripled since the first meaningful censuses were carried out in the 1920s (Samatar 1989a:41). However improvements in the quantity, quality, and access to range forage through implementation of grazing reserves as the primary approach, were unsuccessful (AlNajim and Briggs 1992:358). Although marketing facilities (national and international) were improved, and there was a rise in animal sales, it lagged behind the increment in the livestock population because market facilities did not change the social context of pastoralism; whereby the priority was to sell the smallest number of livestock necessary to maintain and increase herd size, and to obtain cash needs (Al-Najim and Briggs 1992:361). Thus sales increases did not reduce pressure on the rangelands (Al-Najim and Briggs 1992:360). This, together with more constrained livestock movements due to the advance of crop agriculture and development activities, worsened rangeland degradation as livestock densities surpassed the carrying capacity of many interior regions. Consequently each successive drought had greater impact (Bennett 1986:11; Al-Najim and Briggs $1992: 357)$.

\section{Nomadic settlement and the drought of the $1970 \mathrm{~s}$}

Sedentarization efforts began with British and Italian colonial policies to increase the pool of laborers for plantations, and to prevent conflicts associated with livestock raiding (Hitchcock and Hussein 1987:31). After independence settlement was seen as a means to increase agricultural production, increase employment, meet labor shortages, stem urban migration (enhanced by drought), and reduce environmental degradation by reducing the number of pastoralists on the range (World Bank 1981:1; Hitchcock and Hussein 1987:31). Thus in the 1970s the government introduced the Agricultural Crash Program, which established farming cooperatives in ten locations promoting rainfed and irrigated agriculture, but this had little impact on agricultural productivity and employment (Hitchcock and Hussein 1987:31). However despite the efforts by colonial and post-independence governments, until recently little evidence existed of any significant trend toward sedentarization (Samatar 1989a:41).

The drought which peaked in 1974 after four successive years of poor rains was one of the worst in Somalia's history, and resulted in the deaths of some 20,000 people from starvation and malnutrition related diseases. As well, massive losses of livestock were incurred, on the order of 5,000,000 animals, in addition to the loss of tens of thousands of tons of agricultural produce (Hitchcock and Hussein 1987:31). This affected the cooperative movement (Laitin and Samatar 1987:112). The government turned what had been planned as a "Rural Prosperity Campaign" 
including literacy and sand dune stabilization programs, into a desperate famine relief effort (Lewis 1975:1; Laitin and Samatar 1987:112; Hitchcock and Hussein 1987:31). However the government used the situation to further the goals of the overall cooperative program, in essence turning the relief program into a development initiative (Hitchcock and Hussein 1987:38). In 1975, with assistance from the Soviet Union, approximately 120,000 nomads were transported from northern grazing areas to fishing and agricultural cooperatives in the south (Samatar 1989a:9; Laitin and Samatar 1987:111; Gunn 1990:13; Samatar 1993:69). While no surveys were carried out prior to site selection, large irrigation projects were funded by the Kuwait Arab Fund and the World Bank to open up new lands for these nomads, with the government providing some services and purchasing harvests at a preset price as the sole outlet (Samatar 1989a:34; Laitin and Samatar 1987:111). These were in reality state farms, not cooperatives (Laitin and Samatar 1987:111). Because crop failure due to drought is more common than livestock decimation, many participants invested in livestock, as a more secure economic strategy (Hitchcock and Hussein 1987:35). By the end of the 1970s the drought had abated and many men left to rebuild their herds, leaving women and children on the farms. Female headed households, through lack of labor for farming activities, ended up poorer than nonfemale headed households (Samatar 1989a:34; Laitin and Samatar 1987:111; Hitchcock and Hussein 1987:33). Resettlement generated severe strains on local tenure regimes and ecology. Resentment by the host population over the erosion of land rights, along with problems associated with overgrazing, deforestation, land degradation, and declines in agricultural productivity added to the difficulties (Hitchcock and Hussein 1987:38). What began as a relief operation for drought-affected pastoralists ended up being a very expensive program that did not achieve the stated goals of self sufficiency and development (Hitchcock and Hussein 1987:38). The Somali Ogaden war with Ethiopia in 1977-78 increased the number of refugees and associated resource problems in these resettlement areas. The war and the defeat of the somali forces created a refugee crisis, a domestic political crisis, and an economic crisis, the consequences of which reverberated, up to and beyond the disintegration of the state (Laitin and Samatar 1987:1; Clark 1993:111; Hutchison $1991: 83$ ).

\section{Agricultural development and pastoralist resource use}

In the $1980 \mathrm{~s}$ instability in the north led to development activity being concentrated in the central rangelands and in the inter-riverine area (Hutchison 1991:83). This focused on cultivable areas adjacent to the only two perennial rivers, the Shabelle and Jubba. Uncoordinated irrigation development and agricultural expansion along the shabelle river resulted in serious seasonal water shortages (Roth et al 1987:52). And although the Shabelle river receives 90\% of its discharge from the eastern highlands of Ethiopia (TAMS 1986:I-19) no attempt was made to coordinate water use with that country, with whom an adversarial relationship existed. While dry season livestock migrations into the Shabelle river basin produced one of the highest livestock densities in the country (RMR 1984:69), the expansion of crop cultivation decreased seasonal flooding and caused a large reduction in the flood retreat pastures that traditionally served as dry season forage and water areas for nomadic herds (LRDC 1985:36). This exacerbated the problem of locating dry season forage and water for transhumant herders. Along the Shabelle river, and especially near refugee camps, natural resources are severely stressed by overgrazing and deforestation (Drechsel 1989).

The Jubba river valley was also to be developed on a large scale to bring more land under cultivation. The construction of a $\$ 780$ million dam at Bardera was to facilitate the integrated development of this region (Hitchcock and Hussein 1987:31; 
Hutchison 1991:85). However this effort was suspended with the difficulties of the early 1990s.

Efforts to increase the area under crop cultivation were made without considering the integration of local ecology, livestock systems, or traditional agricultural methods in the development of a multi-faceted, risk minimizing, drought survival strategy for the different production systems dependent on any single area (Samatar 1989a:45). In particular, many development and government land use efforts in the country ignored how development activities affected grazing patterns, and the impacts that alterations in such patterns had on food security for the large number of pastoralists. Also not considered was the role that livestock played as a fallback food supply for agriculturalists in times of drought and crop failure (Samatar 1989a:45).

The disruption of migratory patterns of nomadic pastoralists and their herds due to the location of agricultural development projects and the extension of cultivation in river basins and floodplains is a widespread problem facing arid and semi-arid Africa (Scudder 1989:6; Markakis 1993:4). Such growth usually excludes transhumant herds which use these areas for dry season grazing and watering. Unavailable or unaccessible forage in one part of the yearly travels of livestock herders can have disastrous effects on other larger areas, because the herders are then forced to use range resources that are already marginal during the dry season (Biswas et al 1987:427; Box 1971:228). As pastoralists leave degraded areas, they are often obliged to migrate to areas already occupied by other herders and farmers. This leads to overgrazing and conflict as more animals compete for resources that previously sustained less livestock (Unruh 1991:93 and the references cited therein). Agreements between clans and lineages over territorial grazing and watering rights can break down as more herding groups find they cannot gain access to traditional sites, or find that these sites are becoming more crowded and/or degraded (Biswas et al 1987:427; McCabe 1990a:147). Likewise, herders stressed by deteriorating rangeland conditions cannot adequately defend their territories from invading groups. Such degradation places nomadic pastoralists, their herds, and the range, in a position of increased vulnerability to drought; the severity of drought impacts being determined by the prior condition of the rangeland (Campbel1 1981:53; Unruh 1991:93).

\section{Resource Disenfranchisement and Land Degradation}

Throughout the Horn disenfranchisement of local populations from customary land and water use rights has been a major factor contributing to conflict, instability, and land resource degradation (Hutchison 1991:136; Ornas 1990:121; Homer-Dixon et al 1993:42). Replacement of customary tenure regimes by national tenure systems and the change in tenure security this has for transient resource users, has unexpected repercussions arising from changes in access to resources. As well, changes in the customary use arrangements of agriculturalists due to tenure machinations affect pastoralist resource use. The 1975 Land Reform Act in Somalia took precedence over customary tenure regimes, and was formulated to give advantage to state enterprises and mechanized agricultural schemes; with limited rights accorded to small farmers, and no rights given to pastoralists in spite of their majority in the population and their dominance in export earnings (Roth and Unruh 1990:2; Samatar 1989a:54). All land was declared to be state owned and administered by the Ministry of Agriculture (Samatar 1989a:53). Arable land could be leased from the government, however pastoralists could no longer claim use or access to land they previously depended upon (Gunn 1990:112). The procedure to register land was cumbersome, required much time and money for small farmers, was centralized in Mogadishu, and was most easily used, abused and manipulated by well connected officials and their associates. This allowed non-locals to gain title to large tracts of land customarily used by small 
scale cultivators, because the latter were unable to compete in terms of the political and capital mobilization necessary to complete the land registration process (Samatar 1989a:54). Dislocated small scale cultivators then shifted to use more marginal land resources.

Small scale cultivators on both rainfed and irrigated land commonly allowed widespread pastoralist access to forage (grazing, fallow, and crop remnant) and water resources, based primarily on connections within the pastoralist community which allowed such arrangements to be mutually beneficial. Operators of large scale, mechanized and intensive agriculture, were much less willing and able to allow similar arrangements.

A frequent use of newly registered large holdings was as 'fodder farms'. In which a parcel of land, usually in the shabelle river valley, would be enclosed, guarded, and pastoralists charged a fee for access to the natural pasture. This resulted in violent conflict as nomads were unwilling to pay for what they previously had access to for free.

Traditional use and access of restricted or scarce resources were primarily based on membership in a lineage, or religious community capable of defending such rights against competitive groups. Rights were not identifiable by geographic boundaries and are a fundamentally different concept than that of territorial ownership, use, and access where a geographic boundary establishes where the rights of one group begin and those of another end (Samatar 1989a:50). Sections of the 1973 Unified Civil Code abolished traditional clan and lineage rights of use and access over land and water resources (Hooglund 1993:161).

The national land tenure system was unrelated to the traditional tenure arrangements practiced by small farmers and pastoralists, and the interaction of these, which was in many cases the defacto regime many herders and farmers were involved in with each other (Unruh 1993b:3; Roth and Unruh 199:2). As a result, multiple tenure claims to land became increasingly common in the 1980s. While there were steps within the national registration program that were intended to avoid this, namely by notifying population centers proximate to the land in question that a party was interested in registration, and by inviting all other claimants to come forward and contest the claim, this and other procedures were frequently sidestepped (Unruh 1993b:3; Samatar 1989a:50). Land tenure dispute resolution mechanisms were inadequate to resolve the many competing claims to land. The dispute resolution mechanisms in place prior to the difficulties of the early 1990 s embraced a variety of means of mediation that were frequently in jurisdictional conflict (Roth et al 1987:28; Samatar 1989a:50). For small holders and pastoralists the most immediate forms of resolution comprised various traditional methods, including: settlement by personal negotiation with the opposing party; the involvement of farmers' committees; intervention by community religious leaders such as sheikhs and imams; and less often, violence. Local administrations also took part in resolving land disputes, as did the Ministry of Agriculture at various levels, and the Somali legal system (Roth et al 1987:28; Samatar 1989a:50). The dispute resolution methods belonging to the different tenure systems were not reconciled with each other, and so frequently operated in ways that were not compatible.

As frequently occurs when local use and access over resources is usurped by outside interests, local inhabitants over-exploit what was formerly theirs, believing that it is better that they continue to benefit as long as possible rather than have outsiders profit (Hutchison 1991:156). 


\section{Background}

\section{The Somali Segmentary Social Order, Land Use, and Conflict}

Genealogy is the main organizing principle of the Somali social system (Samatar 1993:71). The arrangement is characterized by competition and conflict between clans, lineages and their further segmented units (Laitin and Samatar 1987:29; Clark 1993:110; Samatar 1993:71; Poulsen 1990:139). Each level of segmentation defines the rights, obligations, and relative standing of persons (Samatar 1993:71; Laitin and Samatar 1987:31; Gunn 1990:114). The multiple layers of alliance in which each nomad finds him/herself reveals the different levels at which competition occurs and the need for security exists (Bennett 1991:31). Because every person is a member of several lineage segments or subgroups which have alliances with lineage segments of other clans, a particular nomad's political allegiance is constantly shifting. A pastoralist's own situation with regard to the needed access to resources, and other factors, determine the relative importance of these various identities (Bennett 1993:31). As conditions and situations change so does a nomad's allegiance. Segmentation and structural instability are common among nomadic pastoralist societies, primarily due to the considerable territory required for grazing (Laitin and Samatar 1987:158; White 1990:241; Bennett 1993:20, Storas 1990:138). Traditionally the primary unit for somali social and political action is the diyapaying unit. This consists of a number of families (200-2000) of an immediate lineage who are unified by their collective obligation to pay or receive compensation for infractions such as homicide (Laitin and Samatar 1987:30; Lewis 1961:127; Ofcansky 1993:198). Among the more sedentary inter-riverine population in Somalia the importance of descent has given way partially to territoriality as an organizational framework (Laitin and Samatar 1987:29).

Power in Somalia operates by temporary coalitions and alliances between lineages and their divisions, facilitated by a diffusion of political authority, a lack of stable and formally defined political roles, and virtual autonomy of herd managing units that comprise an extended family or group of families (Samatar 1993:93, Doornbos 1993:100, Lewis 1961:127; Compagnon 1992:10). Such organizational flexibility, or 'low investment politics' is a general feature of east African pastoral communities, and appropriate to highly variable, unpredictable natural environments and external situations (Dyson-Hudson 1985:166). A given alliance can fragment into competitive units as soon as the condition that necessitated it ceases to exist, or more favorable arrangements present themselves or are desired, ie., as when new or alternative grazing and watering areas are required (Samatar 1993:93; Markakis 1993:8; Lewis 1961:127). In such a system there are no permanent enemies or friends only a relevant context in an endless shifting of affiliations that are one of the more important hallmarks of Somali pastoral clan politics (Samatar 1993:93). Such an arrangement however serves the pastoralist poorly in interactions with the state (Markakis 1993:8, Markakis 1993:1).

While the Somali government exercised a measure of central authority through the military and civilian bureaucracy, most somalis gave greater loyalty to their lineages (Laitin and Samatar 1987:30); and the pastoral ethic of clan socialism continued to operate, and in some ways was exacerbated by urban settings (Laitin and Samatar 1987:46; Compagnon 1992:10).

A significant political consequence of the Barre regime was the intensified identification with traditional clans (Hooglund 1993:163). In the decade prior to the collapse of the Somali state, historical animosities between clans grew to clanbased insurgent movements, which became opposed to the Barre government (Ofcansky 1993:187; Compagnon 1992:11). However there was no significant coordination or cooperation between the various armed fronts (Compagnon 1992:10). 


\section{The Social Order, Land Use and Conflict}

Rights of access to land and water for individual households customarily are based on lineage membership; making agreements between clan units decisive in who has access to what land and water. In the ecologically fragile arid and semi-arid environment, such regulation is very important in preventing land degradation and ensuring long term productivity of the range (Ornas 1990:121; Samatar 1989a:38; Poulsen 1990:143) .

Thus pastoralist households have access to social-ecological zones of changing size and shape, depending on the transient agreements between various lineage segments and the relative ecological endowment of different grazing locations (Helander 1986:96). These zones represent a perception of both social and biophysical space where the correlation is not one to one, which increases the choices available in decision-making. In other words pastoralists must consider tradeoffs associated with moving to good pasture where bad social relations exist, versus an area with good social relations but a poorer biophysical environment for grazing, and all variations between these (Helander 1986:97). Thus the mix of genealogical relations, seasonal resources and personal relations combine in different ways to govern herding and migration decisions (Helander 1986:106) . Such decision-making varies with context. Social and/or environmental risks can be gambled with given the influences that development, environmental stress, and conflict have on pastoralist production. These influences and the resulting desperation can determine the nature of 'the gamble' that pastoralists are willing to make to gain at least the minimum resources necessary to maintain the household and herd. Where alliance-based territorial boundaries are part of such a gamble, then these can form the basis for potential conflict in times of political tension or drought (Hutchison 1991:105). When the social customs of herding that prevent overuse of rangeland are disrupted by conflict, movement of herds to seasonal grazing areas are also disrupted, with the result being that pastoralist migrations become governed to varying degrees not only by the eroding and confused agreements between lineage segments, but as well by the pastoralists' own perception of the conflict situation.

\section{Resource Deterioration, Inaccess, and Clan Arrangements}

As more land was being removed from customary use, especially in the 1980s, and environmental stress and resource access issues gained importance for pastoralists. Herding groups increasingly found that they could not gain access to adequate resources.

Where agreements for access to resources could not be, or were not made due to increasing competition, use was made of areas which were previously avoided either because they were contested, or were held by several lineage units in reserve for dry season and drought grazing. This generated conflict, as did simply utilizing grazing land without permission. With less scope for making agreements, pastoralists employed aggressive encroachment and defense based on supremacy of force (Lewis 1961:248). In the past the combination of dwindling resources (on a smaller scale) together with territorial intrusion led to clan wars (Bennett 1993:28). These were especially acute in the dry seasons.

Conflict over resources can have repercussions as old transgressions and latent hostility are aroused and find fresh scope for expression (Lewis 1961:246). This can have real significance at higher lineage levels, ie., involving more people, because the clan system lacks a concept of individual culpability (Samatar 1993:93; Helander 1986:101; Fadal 1984:74; Lewis 1961:45). Perceived transgressions are seen as the responsibility of all the perpetrator's kin, who are guilty by reason of blood connection. Revenge or compensation are therefore sought from any member of the lineage. Localized conflict can escalate into wider resource access problems 
between lineages and segments thereof (Helander 1986:101) and these can influence intra- and inter-clan alliances (Lewis 1961:45).

In the widespread insecurity of the late 1980s and early 1990s, the propensity for disagreements over grazing and watering access to quickly escalate, and/or become situated within the larger conflict, thereby exacerbating insecurity at both scales, greatly increased. Relatively minor conflicts over grazing territory or watering points could easily trigger responses among groups opposed in the wider civil unrest. As well, members of opposed groups in the larger conflict would likely be more prone to discord over resource access than otherwise (Laitin and Samatar 1987:162).

\section{Conflict in Agronomically High Potential Areas}

In the late 1980s the spatially limited, fertile, well watered areas such as the Shabelle river basin became increasingly unstable. Repeated inflows of both pastoralist and agriculturalist refugees arrived fleeing insecurity and food shortage as their own drought, famine and conflict coping strategies were progressively exhausted. This exacerbated the subsequent crowding and competition for resources. In northern somalia this was aggravated by government forces who poisoned wells in rural areas (Laitin 1993:137). As this situation progressed, hostilities increased as the social cohesiveness of past multiple resource use arrangements broke down.

These high potential locations had long been occupied by agriculturalists and by seasonal concentrations of pastoralists, in addition to earlier waves of refugees from the various droughts and wars in the 1970s and 1980s. Local fuelwood sources were depleted to the point where long distance transport of wood and charcoal was both a necessity and a thriving business and cooperative pursuit prior to the collapse of the Somali state. From the late 1980s and early 1990s however transport of fuelwood and food to these areas became problematic due to deterioration of roads and the presence of land mines, and general insecurity.

As decreasing food and fuel availability to large numbers of people acted together with the perception of a continually worsening situation in the economy, and political and ethnic rivalries, the forces of confrontation erupted into violent conflict. Figure 2 illustrates for southern Somalia that the areas of most intense armed conflict were along the shabelle river valley, the most agronomically endowed part of the country.

\section{Collapse of the Somali State and Subsequent Pastoralist Decision-Making}

The pastoralist segmentary social order is vulnerable to external manipulation, such as occurred during the Siad Barre administration (Laitin and Samatar 1987:46). Politicians found it convenient to disburse scarce national resources through the clan structure, as ethnic support is essential for political success (Laitin and Samatar 1987:46). Interclan rivalries were intentionally exploited, and entire clans were rewarded or punished collectively (including the distribution of development projects) in order to obtain objectives and divert attention from an increasingly unpopular, weakening and vulnerable regime (Samatar 1993:93; Laitin and Samatar 1987:159; Bennett 1993:67). Mass desertions from the army by forced conscripts put more weapons in the hands of opposition groups (Hutchison 1991:85). By mid 1990 all aid programs were halted, imports and exports ceased, and hyperinflation made the currency worthless. For a country dependant on international welfare the consequences were devastating, with conflict, starvation, malnutrition and epidemic diseases widely reported (Hutchison 1991:85). Eventually the scale of disruption due to interclan conflict progressively limited the government's reach, until ultimately the streets of the capital were ungovernable (Hutchison 1991:85). 
Deliberately poisoned wells and destruction of reservoirs, and grazing areas, machine-gunning of livestock herds, and indiscriminate bombing of cities within the traditional territory of opposition clans caused the deaths of thousands of people and hundreds of thousands of animals (Hutchison 1991:116; Hooglund 1993:154; Clark 1993:111). Food destined for refugees was confiscated by the army, and foreign relief aid was diverted to support the military (Hutchison 1991:126) and to use as a weapon against groups opposed to the government. The disaffection generated by these and similar policies carried out against important lineages of somali society, and the subsequent organized armed resistance resulted in the collapse of the Barre regime and the Somali state (Clark 1993:112). The subsequent power struggle among clan and region-based groups over resources and the spoils of state led to the ensuing civil war. Militias belonging to various clans eventually divided the country up into 12 zones of control. At the same time persistent drought forced many Somalis from home areas in a desperate search for food, exposing them directly to violence (Clark 1993:112).

The degree of violence in such conflicts is affected by the acquisition of modern weaponry (Hutchison 1991:115). In Somalia the emptying of the country's armories into the general population, along with arms from Ethiopia's crumbling army (Clark 1993:112), obliterated damage limitation in conflict (Hutchison 1991:105), and heightened degree of violence so as to cause a shift in the magnitude and nature of conflict problems. These weapons allowed banditry to disrupt and loot an estimated 80 percent of relief supplies escalating the severity of the famine in the early 1990s, forcing an estimated 800,000 to 900,000 somalis into exile in neighboring countries, while more than one million internally displaced persons fled to urban areas (OFDA 1993:1; Clark 1993:113). An estimated 4.5 million people required external food aid, including approximately 1.5 million at severe risk of starvation (OFDA 1993:1; Clark 1993:113). This led to the U.N. Security Council authorized Unified Task Force (UNITAF) to intervene militarily with the mission of securing humanitarian routes for the delivery of food and other supplies (OFDA 1993:1; Clark 1993:109).

Nomadic resource use during the period of widespread civil unrest operated in a context of considerable fluidity, with coalition cohesion regarding land and water resources becoming increasingly confused, transient, and less meaningful as the traditional authority of clan elders was undermined by modern weapons (Clark 1993:112). This combined with a multiplication of conflict episodes complicated by increasing instances of both clan and non-clan related banditry and the inability to distinguish between these. Nevertheless clan divisions, often operating in the traditionally decentralized fashion, influenced the continuing violence (Ryle 1992:162; Clark 1993:110). As Somali pastoralists armed themselves for their own protection, confrontation became more frequent in the search for adequate resources, as insecurity became the dominant context within which pastoralist decisions were made.

For those still possessing herds or herd fragments, such decisions likely functioned from a combination of perceived biophysical, social, and conflict zones, all geographically defined. However with instability the dominant element, resource access was pursued within the context of much shorter planning horizons and an enormous increase in the set of possible processes and conceivable outcomes brought on by the general insecurity and resulting turbulence (Hutchison 1991:90). Thus while the number of possible decisions for pastoralists increased, spatial and temporal disarray in the socio-biophysical mix meant that expected outcomes from specific decisions did not exist with the same certainly they might have previously.

Conflict zones can be thought of as being comprised of perceptions of security threats of specific frequency and severity, spatially and temporally defined.3 
Pastoralist perceptions of insecurity are informed by information on conflict zones and conflict events. This can take the form of personal experiences, related experiences, and other reports involving varying degrees of factual information, speculation and rumor. These can greatly influence decisions to: migrate more or less often; slaughter animals (usually other than breeding stock first); travel to clan homeland areas or other destinations; time movements differently; and fragment herds among family members according to the animal's age, sex or species in order to exploit specific ecological and social resources, or according to each species' ability to handle worsening conditions (Samatar 1989a:38).

Conflict plays a large role as pastoralists seek to identify feasible and nonfeasible combinations of threats, opportunities, risks and trade-offs in decisionmaking (Ornas 1990:118; Hutchison 1991:145). Getting to socially and biophysically secure areas may require travel through potentially insecure areas, and in times of widespread conflict, confrontation can have a very high cost because--in addition to loss of life--loss of stock does not carry with it the possibility for compensation from the perpetrator's clan as it might have otherwise (Laitin and Samatar 1987:21). While the relationship between social and conflict zones might in some cases be straightforward for a pastoralist--not using grazing areas belonging to a lineage segment opposed to the pastoralist's own in the larger conflict--the relationship between conflict and the biophysical options might be less easy to predict. Decisions to migrate with herds to what the pastoralist recalls as being a biophysically favored location, can reveal the location to be degraded and/or crowded upon arrival. At the same time herders may be confronted with new conflict related hazards affecting grazing areas, such as the presence of land mines and poisoned or destroyed watering points (USIP 1993:2). Such a situation then obligates the pastoralist to move to progressively riskier locations. Aperiodic movements of nomads and their herds have been observed to increase enormously during conflict, as herders increasingly set off to lesser and lesser known pastures in a last ditch effort to save stock (Warshall 1991:107).

Typical strategies, such as selling animals, and dependence on others within the community for assistance, were less of an option given the total breakdown of the Somali economy and the subsequent anarchy and disintegration of community cohesion (Bennet 1991:103). Other options not usually viable in more secure circumstances, such as raiding, invading cropped areas for forage, fleeing to Ethiopia, and incorporating feeding centers into survival strategies, were employed. In the late 1980s nine refugee camps were established in Ethiopia, situated within the territory of Somali pastoral clans (Ryle 1992:160). These provided refuge from the instability in Somalia, as well as food and water for residents and other clan members. In some cases these camps became incorporated into seasonal migrations with clan members going to the camps in the dry season because of the unavailability of grazing areas due to the conflict (Ryle 1992:163).

While pastoralist decision-making during insecurity acts to maximize household chances of survival, the result can be the contribution to an unsustainable and a continuing unstable collective consequence (Samatar 1989a:63). Through long-term vegetative degradation and aggressive confrontation in order to attain resource access, the foundation for the pursuit of resource use strategies in a context of security, is compromised. Over-exploitation of vegetative species can require long periods of time to recover, especially for trees, which are important to browsers. As well increasing contention over access to diminishing secure resources can exacerbate the turmoil and confusion over what might constitute commonly acceptable resource use arrangements. The result of this is to continue the basis for disorganization and chaos until a shared sense of purpose becomes part of pastoralists' lives again, and/or part of the strategic vision of leadership at the local, regional, or national level (Samatar 1989a:63). 


\section{Future of Pastoralism}

While the rehabilitation of the pastoralist sector will necessarily play an important role in the recovery of Somalia, at the same time it presents a dilemma. Although pastoralists comprise the numerical majority in the country, there is considerable discussion as to whether anything close to a traditional pastoral strategy will be able to continue in Somalia and elsewhere on the Horn (Laitin and Samatar 1987:127; Fadal 1984:84; Hutchison 1991:101; Baxter 1993:143; Morton 1993:30; Poulsen 1990:147; Bennett 1991:41). Environmental stress, and limitations placed on migrations and resource access will likely lead increasingly to inaccess to the material base for such a strategy (Korkfors 1984:306; Markakis 1993:1). Disintegration of the economic and social tenants of traditional pastoralism in Somalia have been underway since the colonial era (Fadal 1984:71; Bennett 1986:150; Samatar 1989a:45). As elsewhere on the continent, traditional pastoralist society has not managed well the changes being thrust upon it (Bennett 1986:150). Underlying causes include the introduction of modern forms of transport, employment possibilities in the rapidly developing Gulf states, the development of productive forces in the cities and the growth of market relations, the progression of moneycommodity relations within the pastoral economy, market demands for livestock products and the subsequent economic drive to increase production, the breakdown of traditional social and economic ties to family and group, clan rivalries, conflict, the role of a central authority, and development programs such as veterinary services and water development (Fadal 1984:76; Hutchison 1991:102; Poulsen 1990:148). The impact of these influences was to substantially weaken the ability of pastoralism to reproduce itself (Fadal 1984:79).4

From a development perspective however, settling pastoralists permanently into exclusively farming or fishing pursuits has not been successful (Samatar 1989a:42). Sedentarization of large numbers of pastoralists may be especially impractical considering the limited spatial extent of arable lands in Somalia, and that many farming areas are already crowded. Development efforts must recognize that some form of pastoralism will be essential to the nation's ability to feed a growing population from a land resource covering large areas with few alternative uses. Arrangements involving somali generated adaptations to resource use changes including variations of agropastoralism and multiple access and use of the spatially limited arable lands should be explored, within the political character of somali society. New models of resource tenure must be designed to meet the circumstances of a changing pastoral production system, given the spatial and temporal variation in resources (Bennett 1986:150). However new approaches need to recognize, that no development initiative or technological system will remove the occurrence of drought and that livestock herding as a drought avoidance strategy will remain a central objective of many local pastoralists (Samatar 1989a:67).

\section{Restocking of Pastoralists}

For such adaptations to evolve, restocking pastoralists is a near-term development priority. However drought, conflict, famine and subsequent food distribution programs undermine traditional indigenous restocking mechanisms (McCabe 1990b:147). These mechanisms are usually based on contributions of animals by fellow stock-owners with whom exchange relationships exist, and carry with it an assurance of reciprocity (McCabe 1990a:156; Hitchcock and Hussein 1987:31). Animal loans to completely destitute pastoralists in refugee camps do not carry the same assurance. Once social exchange networks have been disrupted, herders in famine relief camps frequently find it very difficult to return to a pastoral life. There is increasing recognition of the need to design better recovery mechanisms for 
refugee pastoralists given their generally reduced capacity for recovery (Toulmin 1987:130; Moris 1988:287).

Evaluations should assess the capacity and rate with which pastoral production systems can rehabilitate themselves without external intervention, so as to compare expected rates of recovery with external intervention, and the associated costs, versus the cost of prolonged famine relief (Toulmin 1987:130). However recovery does not occur in isolation. A number of production systems each with large numbers of participants may attempt drought or famine rehabilitation at the same time, most likely in the same spatially limited 'agronomically high potential' areas. Recovery rates of various production systems may or may not be compatible. Indigenous rates of recovery for pastoralism for example may entail lengthy year-around occupation of farming areas which are also important in sustaining large agricultural and growing urban populations. Incompatibilities in land use can lead to conflict and accelerate land degradation, reducing further the productive capacity of scarce land resources (Unruh 1993a:306). Intervention to speed rates of recovery must be based on more than single production systems.

Approaches to restocking destitute nomads must build upon traditional institutions in order to rebuild herds in culturally relevant ways, so that maximum efficiency in restocking is ensured. Such mechanisms are part of coping strategies that have evolved to meet the challenges of existence in precarious environments given in-place cultural, ecological, and socio-political constraints and opportunities.

\section{Notes}

1. Somalia encompasses approximately $638,000 \mathrm{~km}^{2}$, and is divided into five general biophysical zones (Poulsen 1990:138; Samatar 1993:63; Samatar 1989a:11). The eastern highlands are dominated by the Karkaar mountains, where the comparatively high but scattered precipitation supports forest vegetation dominated by Gummi

arabicum; here incense and myrrh collection comprise the primary vegetative resource. The area is of limited utility to pastoral production due to the rocky surface. Southward of the Karkaar mountains is a region of broken mountain terrain and shallow plateau valleys known as the Ogo.

The central high plateau, or the Haud, straddles the Ethiopian-Somali border and extends more than $60 \mathrm{~km}$ into Ethiopia, and south and eastward into central and southwest Somalia. This region is characterized by relatively dense bush vegetation and grasses comprising some of the best grazing areas in the country. Within the plateau are a number of low depressions where water is present into the dry season, supporting vegetation for much of the year.

The central Mudug Plain is made up of smaller terrace-like plains rising gently between the Haud and the coastal plains. Along the northern edge of the plain is the Nugaal valley with its extensive network of seasonal streams. Precipitation is generally less in this region than in the Haud and on the coast, and the vegetation is more scattered and dominated by species of acacia in the form of thorny bushes and scrub. Surface and subsurface water is usually scarce except during the rainy season when water collects in natural depressions. Where permanent wells exist some type of permanent or semi-permanent settlement is usually present.

The inter-riverine area lies between the only two perennial rivers in the country, the shabelle and the Jubba, and comprises the country's major agricultural area due to favorable rainfall and soil conditions. Because of the perennial water supply, farmers inhabit many locations permanently, and most Europeans settled here during the colonial era. This is also the region where the greatest interaction between pastoralists and agriculturalists occurs, and a large agropastoral sector exists in the south-central part of the country (Massey 1987:1; Massey 1989:163). 
The coastal plains are characterized by coastal sand dunes, especially in the south, and fairly reliable year-round water resources. And although well water is saline in most locations and causes health problems for both humans and livestock, it is widely used, especially during the dry season. The vegetation comprises acacia and a large variety of grasses.

Precipitation is distributed in a bimodal pattern with two alternate wet and dry seasons. The Gu is the major rainy season lasting from April to June, followed by the minor Hagai dry season from July to september. The Der season follows the Hagai and is a minor rainy season lasting from october to December, followed by the major Jilaal dry season from January through March. The rainfall pattern includes scarcity, poor distribution, variability in the onset of the wet season and high variability in the amount of precipitation from year to year. Droughts occur about every four to five years (Handulle and Gay 1987:36; Unruh 1991:103). However FAO probability graphs estimate that partial or complete failure of rainfed crops due to inadequate precipitation is likely to occur as frequently as two years in five (Young 1985:122).

2. The pastoral systems of Somalia are made up of cattle, camels, sheep, and goats. The cattle of southern Somalia are mainly of the East African Shorthorn (thoracic humped) Zebu (EASZ) type. However some cattle show traits of crosses between the EASZ and the other long horned thoracic humped zebu crossbreed cattle typical of Ethiopia and northwest Somalia. In the EASZ type three local breeds are represented, the Cassara, Dawara, and Boran. The crossbred cattle are recognized as the local Surqa breed. Somali camels are of only one type, the single humped dromedary. There are however breed variations associated major geographical areas--southern Somalia, the coast, northern Somalia, and the mountains in the extreme north of the country. Two types of goats are present. The Short Eared East African type (the most predominant) and the Arbed type. Sheep are uniformly of the Somali Blackhead type (LRDC 1985:121).

3. Spatially defined in that the herder has some notion as to the spatial location and extent of conflict areas of varying severity of confrontation and their potential consequences, ie., herd loss, personal security concerns, etc.). Temporally defined in that the degree of insecurity in different areas can change at different rates. Proximity to different areas within the orbit of potential destinations, containing different frequencies and severities of confrontation, require that different planning horizons be pursued in pastoralist decision-making.

4. Markakis (1993) makes a very through documentation of the processes involved in the demise of pastoralism on the Horn.

References

Al-Najim MN, Briggs J (1992) Livestock development in Somalia - a critical reivew. GeoJournal 26:357-362

Baxter PTW (1993) The 'new' east African pastoralist: an overview. In: Markakis J (ed.) Conflict and the Decline of Pastoralism on the Horn of Africa. The Macmillan Press Ltd., London

Bennett JW (1984) Political ecology and development projects affecting pastoralist peoples in east Africa. Land Tenure Center Research Paper No. 80. Land Tenure Center, Madison, Wisconsin. 
Bennett JW, Lawry SW, Riddell JC (1986) Land Tenure and Livestock Development in Sub-Saharan Africa. AID Evaluation Special Study No. 39. US Agency for International Development, Washington DC

Bennett O (ed.) (1993) Greenwar: Environment and Conflict. The Panos Institute, London

Berg E (1982) Encouraging the private sector in Somalia. Report prepared for USAID, Washington DC.

Biswas AK, Masakhalia YFO, Odero-Ogwel LA, and Pallangyo EP (1987) Land use and farming systems in the Horn of Africa. Land Use Policy 4:419-443

Box TW (1971) Nomadism and land use in Somalia. Economic Development and Cultural Change 19: 222-228

Cassanelli LV (1982) The Shaping of Somali Society. University of Pennsylvania Press, Philadelphia

Clark J (1993) Debacle in Somalia. Foreign Affairs 72:109-123

Compagnon D (1992) Political decay in Somalia: from personal rule to warlordism. Refuge $12: 8-13$

Conze P and Labahn P (1986) From a socialistic system to a mixed economy: the changing framework for Somali agriculture. In: Conze P and Labahn P (eds.) Somalia: Agriculture in the Winds of Change. Saarbrucken - Schafbrucke Publishers, Germany

Doornbos M (1993) Pasture and polis: the roots of political marginalization of Somali Pastoralism. In: Markakis J (ed.) Conflict and the Decline of Pastoralism on the Horn of Africa. The Macmillan Press Ltd., London

Drechsel P (1989) Soils and reforestation in the central rangelands of Somalia. Arid Soil Research 3: 41-64

Dyson-Hudson N (1985) Pastoral production systems and livestock development projects: an east African perspective. In: Cernea MM, Putting People First. oxford, Oxford University Press

Fadal MO (1984) The ongoing process of gradual disintegration of the traditional social and economic systems of pastoralism in Somalia. In: Labahn T (ed.) Proceedings of the Second International Congress of Somali Studies. University of Hamburg August 1-6, 1983. Helmut Buske Verlag, Hamburg

Gunn S (1990) Somalia. In: Powelson JP and Sock R (eds.) The Peasant Betrayed: Agriculture and Land Reform in the Third World. The Cato Institute, Washington DC

Handulle AA, and Gay CW (1987) Development and traditional development in Somalia, Nomadic Peoples, 24: 36-43 
Helander B (1986) the social dynamics of southern Somali agro- pastoralism: a regional approach. In: Conze P and Labahn P (eds.) Somalia: Agriculture in the Winds of Change. Saarbrucken - Schafbrucke Publishers, Germany

Hitchcock R, and Hussein H (1987) Agricultural and non-agricultural settlements for drought-afflicted pastoralists in Somalia. Disasters 30-39

Homer-Dixon T, Boutwell JH, Rathjens GW (1993) Environmental change and violent conflict. Scientific American, February:38-45

Hoog R (eds.) Property, Poverty, and People: Changing Rights in Property and Problems of Pastoral Development. University of Manchester, Manchester

Hooglund E (1993) Government and politics. In: Metz HC (ed.) Somalia: A Country Study. Fourth edition, Library of Congress, Federal Research Division, Washington DC

Hurni H (1993) Famine in Somalia: fate or failure? Journal of Soil and Water Conservation 48:20-21

Hutchinson CF (1991) Short FEWS: An action-oriented famine early warning system. In: Famine Mitigation, proceedings of a workshop in Tucson AZ, 31 July - 2 August, 1991, Office of Arid Lands Studies, University of Arizona, Tucson, USA

Hutchison RA (ed.) (1991) Fighting for Survival: Insecurity, People and the Environment in the Horn of Africa. Based on study by Spooner BC, and Walsh $\mathrm{N}$, IUCN, Gland

Krokfors C (1984) Environmental considerations and planning in Somalia. In: Labahn T (ed.) Proceedings of the Second International Congress of Somali Studies. University of Hamburg August 1-6, 1983. Helmut Buske Verlag, Hamburg

Laitin DD, and Samatar SS (1987) Somalia: Nation in Search of a State. Westview Press, Boulder

Laitin DD (1993) The economy. In: Metz HC (ed.) Somalia: A Country Study. Fourth edition, Library of Congress, Federal Research Division, Washington DC

Land Resources Development Center (LRDC) (1985) Land Use in Tsetse-Affected Areas of Southern Somalia. Tolworth Tower, Tolworth, Surbiton, KT6 7DY, UK

Lewis IM (1961) A Pastoral Democracy: A Study of Pastoralism and Politics Among the Northern Somali of the Horn of Africa. Oxford University Press, London

Lewis IM (1975) Abaar: the Somali drought. Emergency Report 1. International African Institute

Markakis J (1993) Introduction. In: Markakis J (ed.) Conflict and the Decline of Pastoralism on the Horn of Africa. The Macmillan Press Ltd., London

Massey G (1987) Subsistence and Change: Lessons of Agropastoralism in Somalia. Westview Press. Boulder, Colorado

Massey G (1989) Agropastoralism and agropastoral society in south-central Somalia. Journal of Developing Societies 5:137-174 
McCabe JT (1990a) Success and failure: the breakdown of traditional drought coping institutions among the pastoral Turkana of Kenya. Journal of Asian and African Studies 25:146-159

McCabe JT (1990b) Turkana pastoralism: a case against the tragedy of the commons. Human Ecology 18: 81-103

Ofcansky T (1993) National security. In: Metz HC (ed.) Somalia: A Country Study. Fourth edition, Library of Congress, Federal Research Division, Washington DC

Office of U.S. Foreign Disaster Assistance (OFDA) (1993) Somalia - civil strife. Agency for International Development, Washington DC

Ornas Af, AH (1990) Pastoral and environmental security in east Africa. Disasters $14: 115-122$

Poulsen E (1990) the changing patterns of pastoral production in Somali society. In: Palsson G (ed.) From Water to World-Making: African Models and Arid Lands. The Scandinavian Institute of African Studies, Uppsala

Resource Management and Research (RMR) (1984). Somali Democratic Republic Southern Rangelands Survey. Vol 4, Part 1, 16B West Central St., London W.C.1.

Roth M, Lemel H, Bruce J, Unruh J (1987) An analysis of land tenure and water allocation issues in the Shalambood irrigation zone, Somalia. Land Tenure Center project report, University of Wisconsin-Madison

Roth M and Unruh J (1990) Land title, tenure security, credit and investment in the Lower Shabelle region, Somalia. Land Tenure Center, Madison, WI

Ryle J (1992) Notes on the repatriation of Somali refugees from Ethiopia. Disasters $16: 160-168$

Samatar SS (1993) The society and its environment. In: Metz HC (ed.) Somalia: A Country Study. Fourth edition, Library of Congress, Federal Research Division, Washington DC

Samatar MS (1989a) A study on drought induced migration and its impact on land tenure and production in the inter-riverine region of Somalia. Food and Agriculture Organization of the United Nations, Rome

Samatar AI (1989b) The State and Rural Transformation in Northern Somalia 1884-1986. The University of Wisconsin Press, Madison, USA

Scudder T (1989) River basin projects in Africa. Environment

$31: 4-32$

Storas F (1990) Intention of implication - the effects of Turkana social organization on ecological balances. In: Baxter PTW, and Hoog R (eds.) Property, Poverty, and People: Changing Rights in Property and Problems of Pastoral Development. University of Manchester, Manchester 
Toulmin C (1987) Drought and the farming sector: loss of farm animals and postdrought rehabilitation. Development policy Review 5:125-148

United States Institute of Peace (USIP) (1993) Special Report II on Somalia. United States Institute of Peace, Washington DC

United States Agency for International Development (USAID) (1979) Somalia: Central Rangeland Development. AID project No. 649-0108, Washington DC

Unruh JD (1991) Nomadic pastoralism and irrigated agriculture in Somalia: utilization of existing land use patterns in designs for multiple access of "high" potential" areas of semi-arid Africa. GeoJournal 25:91-108

Unruh JD (1993a) Restocking refugee pastoralists in the Horn of Africa. Disasters $17: 305-320$

Unruh JD (1993b) Post famine rehabilitation of agricultural production systems in southern Somalia: resource tenure issues in 'high potential' areas. Paper presented at The Fifth International Congress of Somali Studies, December 1- 7, Worcester and Boston, MA

Unruh JD (1993c) An Acacia-based design for sustainable livestock carrying capacity on irrigated farmlands in semi-arid Africa. Ecological Engineering 2:131-148

Warshal P (1991) Cash, cows, and camels: the fate of livestock in African disasters. In: Famine Mitigation, proceedings of a workshop in Tucson AZ, 31 July - 2 August, 1991, Office of Arid Lands Studies, University of Arizona, Tucson, USA

White C (1990) Changing animal ownership and access to land among the Wodaabe (Fulani) of central Niger. In: Baxter PTW, and Hoog R (eds.) Property, Poverty, and People: Changing Rights in Property and Problems of Pastoral Development. University of Manchester, Manchester

World Bank (1981) Somalia Agricultural Sector Review. Report No. 2881a-So. Eastern Africa Regional office, Northern Agricultural Division, Nairobi, Kenya; International Bank for Reconstruction and Development, Washington, DC

Young LA (1985) A general assessment of the environmental impact of refugees in Somalia with attention to the Refugee Agricultural Program. Disasters 9:122-133 